\title{
Peran Hypersay dalam Membantu Dosen Menyampaikan Presentasi Pembelajaran di Tengah Pandemi Covid-19
}

\author{
Ahmad Apriyanto ${ }^{1}$, Sutama $^{2}$ \\ ${ }^{1}$ Pendidikan Teknik Informatika, Universitas Muhammadiyah Surakarta \\ ${ }^{2}$ Pendidikan Matematika, Universitas Muhammadiyah Surakarta \\ Email: $\underline{\text { 7710180119@student.ums.ac.id }}^{1}$, sutama@ums.ac.id ${ }^{2}$
}

\begin{abstract}
Abstrak
Peran media pembelajaran ditengah pandemi Covid-19 sangat membantu dosen dan mahasiswa untuk melakukan kegiatan pembelajaran meski dari rumah. Hypersay adalah salah satu contoh media pembelajaran yang dapat digunakan ditengah pandemi Covid-19. Media tersebut dapat memberikan presentasi interaktif dengan menggunakan file powerpoint biasa dan mengubahnya menjadi sesi langsung. Tujuan penelitian ini adalah 1) menganalisa strategi pembelajaran yang tepat menggunakan hypersay dalam membantu dosen menyampaikan presentasi di tengah pandemi; 2) mendeskripsikan peran hypersay dalam membantu dosen menyampaikan presentasi pembelajaran di tengah pandemi; dan 3) menganalisis dampak penggunaan hypersay dalam pembelajaran di tengah pandemi. Jenis penelitian ini adalah penelitian referensi. Keabsahan data pada penelitian ini dengan berbagai sumber dan perpanjangan waktu. Teknik analisis data penelitian ini dengan metode komparasi konstanta. Hasil dari penelitian ini adalah 1) Dalam menyusun strategi pembelajaran harus memperhatikan beberapa aspek agar mahasiswa tidak terbebani dan dapat memahami materi pembelajaran secara maksimal; 2) Hypersay berperan dalam membantu proses pembelajaran secara online. Salah satunya adalah membantu dosen untuk menyampaikan live presentasi dan memberikan penilaian kepada mahasiswa; 3) Penggunaan hypersay berdampak positif bagi pembelajaran online, karena memiliki banyak fitur yang mendukung.
\end{abstract}

Kata kunci: Hypersay, Pembelajaran, Pandemi

\section{The Use of Hypersay to Help Lecturer to Present Learning Material During Covid-19 Pandemic}

\author{
Ahmad Apriyanto ${ }^{1}$, Sutama ${ }^{2}$ \\ ${ }^{1}$ Informatics Engineering Education, Muhammadiyah University of Surakarta \\ ${ }^{2}$ Mathematic Education, Muhammadiyah University of Surakarta \\ Email:a710180119@student.ums.ac.id ${ }^{1}$, sutama@ums.ac.id ${ }^{2}$
}

\begin{abstract}
The use of media learning during Covid-19 Pandemic could helps lecturer and students to keep learning even from home. Hypersay is an example of media learning that can be used during covid-19 pandemic. This media can make ordinary power point files turn into interactive live session. The aim of this study are 1) To analyze the appropriate strategy of using hypersay to help lecturer present learning material during pandemic; 2) to describe the role of hypersay in helping lecturer to present learning material during pandemic; and 3) to analyze the effect of hypersay to present learning material during pandemic. The validity of this data is by using some study from another research with an extension time. Data comparation is used as data analysis technique in this article. The conclusion of this article are 1) while making strategic learning, requires some aspect so student could enjoy and the material can delivered optimally; 2) hypersay could help in online learning, such as helping lecturer to give live presentation directly and provide assessments to students; and 3) the use of hypersay has positive impact on online learning, because the are a lot of supporting feature.
\end{abstract}

Keywords: Hypersay, Learning, Pandemic 


\section{PENDAHULUAN}

Di tengah pandemi Covid-19 ini menyebabkan seluruh kegiatan yang biasanya dikerjakan diluar rumah untuk saat ini tidak diperbolehkan, karena untuk meminimalisir penyebaran virus Covid-19. Bekerja dari rumah berarti pekerjaan yang dilakukan terutama dari rumah (minimal 20 jam per minggu). Bekerja dari rumah akan memberikan waktu yang fleksibel bagi pekerja untuk memberikan keseimbangan hidup bagi karyawan (Crosbie, 2004). Virus ini memiliki tingkat penyebaran yang sangat cepat dikalangan manusia tanpa memandang usia, sehingga seseorang yang terjangkit virus ini resiko terbesarnya adalah kematian. Oleh karena itu pemerintah menerapkan kebijakan work from home untuk mengurangi penyebaran virus tersebut.

Salah satu yang terkena dampak dari penyebaran virus ini yaitu bidang pendidikan. Oleh karena itu, semua aktivitas belajar mengajar yang semula dilakukan secara tatap muka sekarang dilakukan secara online. Hal ini menyebabkan mahasiswa dan dosen harus lebih memahami tentang media pembelajaran jarak jauh supaya proses belajar mengajar tetap dapat dilaksanakan meskipun dari rumah. Istilah e-learning lebih tepat ditujukan sebagai usaha untuk membuat sebuah transformasi proses pembelajaran yang ada di sekolah atau perguruan tinggi ke dalam bentuk digital yang dijembatani teknologi internet (Munir, 2009: 169). E-Learning adalah pembelajaran berbasis pada jaringan internet yang dapat dilakukan dengan tidak dibatasi tempat dan waktu (Epignosis, 2014).

Dengan model pembelajaran jarak jauh tersebut memberikan dampak yang kurang baik bagi dosen, mahasiswa dan lembaga pendidikan. Hal ini dikarenakan pembelajaran jarak jauh bisa dikatakan lebih rumit apabila kurang mengetahui media pembelajaran jarak jauh, terlebih bagi mahasiswa yang mempunyai koneksi internet kurang memadai. Disisi lain beberapa dosen hanya memberikan sebuah file presentasi dan kemudian diakhir slide diberikan tugas tanpa penjelasan sebelumnya. Sehingga pembelajaran dari rumah ini dirasakan mahasiswa lebih berat dan kurang nyaman, karena dosen lebih banyak memberikan tugas daripada materi.

$$
\text { Terdapat beberapa media }
$$
pembelajaran jarak jauh yang belum diketahui dosen untuk melaksanakan pembelajaran secara daring. Media tersebut dapat memudahkan dosen sekaligus mahasiswa, sehingga pembelajaran terasa nyaman dan tidak membosankan. Hal ini dapat memacu semangat mahasiswa dalam melakukan pembelajaran, karena di tengah pandemi ini mahasiswa harus tetap giat belajar dan menjaga kesehatan. Sehingga pembelajaran harus dibuat senyaman mungkin dan tidak terlalu membebani mahasiswa, yaitu dengan menggunakan media pembelajaran Hypersay. 
Penggunaan hypersay dianggap dapat membantu memudahkan proses belajar mengajar di tengah pandemi Covid19. Hal ini dikarenakan fitur yang terdapat di media tersebut sangat mendukung dan memudahkan pembelajaran online, antara lain guru dapat melakukan live presentation, live quiz tanpa perlu berpindah ke media pembelajaran lainnya, sehingga pembelajaran lebih efektif dan efisien. Kemudian diakhir pembelajaran guru dapat memberikan penilaian dengan mudah, karena media ini menyediakan fitur berupa grafik penilaian yang ambil berdasarkan keaktifan mahasiswa selama pembelajaran berlangsung. Fitur ini sangat membantu bagi dosen untuk memberikan penilaian secara maksimal kepada mahasiswa ketika pembelajaran dilaksanakan secara online.

Berdasarkan pengamatan yang dilakukan oleh peneliti di lingkungan kampus Universitas Muhammadiyah Surakarta (UMS), Sekolah Menengah Pertama (SMP) dan Sekolah Menengah Atas (SMA), penggunaan media pembelajaran hypersay masih tergolong cukup rendah. Hal ini dikarenakan pemahaman yang kurang mendalam mengenai media ini dan kurang terdengar familiar dibandingkan dengan media lain seperti zoom dan google meet. Sehingga ketika dosen menggunakan media ini kemungkinan menemukan kendala kecil. Akan tetapi ketika dipelajari lebih mendalam, media ini dapat memudahkan dosen dalam melakukan pembelajaran jarak jauh dan lebih terasa fitur-fitur yang terdapat di dalamnya sehingga mahasiswa pun lebih nyaman menggunakan media ini.

Berdasarkan uraian diatas, perlu diadakannya kajian pustaka sebagai dasar dari pembuatan artikel ini. Hypersay adalah produk dari Learn Forward, EdTech startup yang berkembang di London. Perusahaan ini didirikan oleh Paul balogh dan Cristian dinu pada tahun 2016. Hypersay adalah platform untuk presentasi interaktif yang mengambil file powerpoint biasa dan mengubahnya menjadi sesi langsung, menghubungkan presenter dan presentasi dengan audiens melalui smartphone, tablet atau laptop mereka sendiri tanpa aplikasi untuk diunduh - hanya Universal Resource Locator (URL) web sederhana.

Pembelajaran adalah perubahan atau kemampuan seseorang yang dapat dikekalkan tetapi tidak disebabkan oleh pertumbuhan. Perubahan yang dipanggil pembelajaran diperlihatkan melalui perubahan tingkah laku; dengan membandingkan tingkah laku seseorang individu sebelum didedahkan kepada situasi pembelajaran dengan tingkah lakunya selepas didedahkan dengan situasi pembelajaran (Robert M Gagne, 1970). Pembelajaran adalah perubahan tingkah laku yang kekal hasil dari pengalaman. Perubahan ini mungkin tidak jelas sehingga timbul suatu situasi yang menonjolkan tingkah laku baru ini; pembelajaran biasanya tidak diperlihatkan dengan serta-merta 
melalui pencapaian (E.R. Hilgard, R.C. Atkinson dan R.L. Atkinson, 1975). Pembelajaran adalah proses di mana pengalaman menyebabkan perubahan dalam pengetahuan dan tingkah laku yang kekal (Anita E. Woolfolk, 1995).

$$
\text { Media dalam pembelajaran }
$$
berfungsi memperjelas pesan yang disampaikan guru. Media juga berfungsi sebagai alat bantu mengajar (Sudjana \& Rivai, 2011). Media pembelajaran berfungsi untuk menghadirkan objek yang tidak dapat dilihat siswa secara langsung atau obyek yang terlalu mikro untuk dapat dilihat langsung, misalnya memperbesar benda yang kecil, menyajikan peristiwa yang letaknya jauh, kompleks, rumit, yang berlangsung dengan sangat cepat atau lambat, menjadi lebih sistematik dan sederhana (Susarno, 2010). Media pembelajaran merupakan sarana agar peserta didik tidak jenuh dalam mengikuti pelajaran dan efek yang terbesar diharapkan peserta didik dapat termotivasi dan mempermudah dalam menerima materi pelajaran (Fanny: 2013).

Umat manusia dewasa ini sedang berada dalam kesedihan mendalam akibat mewabahnya Coronavirus Disease (Covid19) yang melanda hampir di seluruh belahan dunia (Mahase, 2020). Pandemi Corona Virus Disease 2019 (COVID-19) diumumkan World Health Organization (WHO) tanggal 11 Maret 2020. Kejadian Covid-19 yang dilaporkan kepada publik pertama kali tanggal 31 Januari 2020 di Wuhan, Propinsi Hubei, RRC. Berbagai negara telah menerapkan isolasi, yaitu pemisahan orang sakit dengan penyakit menular dari orang yang tidak terinfeksi untuk melindungi orang yang tidak terinfeksi (Smith \& Freedman, 2020). Diterapkan pula karantina, yakni pembatasan pergerakan orang yang diduga telah terkena penyakit menular tetapi tidak sakit, baik karena mereka tidak terinfeksi atau karena mereka masih dalam masa inkubasi (Smith \& Freedman, 2020).

Beberapa negara di dunia telah melakukan penyesuaian pembelajaran akibat adanya pandemi Covid-19 ini. Melalui surat edaran Kementrian Pendidikan dan Kebudayaan, pemerintah mengeluarkan Surat Edaran Nomor 4 Tahun 2020 tentang "Pelaksanaan Kebijakan Dalam Masa Darurat Penyebaran Corona Virus Disease (Covid-19). Kemudian pemerintah memperkuat Surat Edaran Kementrian Pendidikan dan Kebudayaan dengan menerbitkan Surat Edaran Nomor 15 Tahun 2020 tentang "Pedoman Penyelenggaraan Belajar Dari Rumah Dalam Masa Darurat Penyebaran Covid-19. Dalam surat edaran ini disebutkan bahwa tujuan dari pelaksanaan belajar dari rumah adalah memastikan pemenuhan hak peserta didik untuk mendapatkan layanan pendidikan selama darurat Covid-19.

Berdasarkan surat edaran tersebut, seharusnya tenaga pendidik (Dosen dan 
Guru) memberikan pelayanan yang maksimal sebagai pemenuhan hak peserta didik dalam kegiatan belajar selama pandemi ini berlangsung. Akan tetapi survei yang dilakukan oleh komisioner Komisi Perlindungan Anak Indonesia (KPAI) pada tanggal 13-27 April 2020, yang mencakup 1.700 anak sekolah di 20 provinsi. Hasil survei ini menunjukkan sebanyak 79,9\% responden menyatakan bahwa Pembelajaran Jarak Jauh (PJJ) berlangsung tanpa interaksi Guru dan Siswa/Dosen dan Mahasiswa dalam tingkat perguruan tinggi. Kemudian $20,1 \%$ responden yang menyatakan ada interaksi antara siswa dengan guru selama Pembelajaran Jarak Jauh berlangsung.

Hal tersebut dapat dijadikan tolak ukur bahwa pembelajaran pada masa pandemi ini pelayanan yang diberikan oleh tenaga pendidik kepada peserta didik kurang maksimal antara lain pemberian sebuah materi tanpa sebuah penjelasan akan membuat siswa/mahasiswa bingung dalam memahami materi tersebut, kemudian alasan yang paling umum tidak menyukai pembelajaran jarak jauh adalah tugas-tugas yang diberikan terlalu berat, padahal pada saat belajar di sekolah seperti biasa tidak seberat itu tugasnya.

Dengan kondisi yang seperti ini, seharusnya dosen ketika melakukan pembelajaran jarak jauh tidak memberatkan mahasiswanya dengan tugas. Akan tetapi agar lebih tercapai tujuan belajar yaitu dosen lebih mengutamakan keyamanan mahasiswanya dalam belajar sehingga dapat menyerap materi yang diberikan. Salah satu contohnya yaitu menggunakan media hypersay dalam melakukan presentasi pembelajaran, membuat kuis pembelajaran dan penilaian pembelajaran yang sangat membantu dosen ketika pembelajaran secara daring.

Berdasarkan uraian tersebut, tujuan penelitian pada artikel ini ada tiga, yaitu 1) menganalisis strategi pembelajaran hypersay dalam membantu dosen menyampaikan presentasi di tengah pandemi; 2) mendeskripsikan peran hypersay dalam membantu dosen menyampaikan presentasi pembelajaran di tengah pandemi; dan 3) menganalisis dampak penggunaan hypersay dalam pembelajaran di tengah pandemi. Adapun manfaat penelitian pada artikel ini adalah untuk memudahkan dosen/guru dalam melakukan pembelajaran dan penilaian di tengah pandemi.

\section{METODE}

Jenis penelitian yang digunakan adalah penelitian referensi. Penelitian referensi adalah penelitian yang sumber datanya berasal dari beberapa referensi yang relevan, yaitu pengambilan datanya berorientasi pada beberapa referensi yang sesuai (Sutama, 2019). Dalam artikel ini, pengambilan data diperoleh dari beberapa jurnal yang berkaitan dengan media pembelajaran. 
Obyek penelitian dalam artikel ini adalah hypersay. Hypersay adalah platform untuk presentasi interaktif yang mengambil file powerpoint biasa dan mengubahnya menjadi sesi langsung. Dengan adanya media ini diharapkan dapat memudahkan mahasiswa dan dosen dalam melakukan pembelajaran di tengah pandemi.

Keabsahan data dalam artikel ini adalah dengan berbagai sumber dan perpanjangan waktu. Triangulasi sumber artinya suatu data diambil dari beberapa sumber lalu diperoleh data yang sah dan sama (Sutama, 2019). Triangulasi perpanjangan waktu adalah data diperoleh dari waktu yang diulang-ulang dan berbeda sehingga diperoleh data yang sah dan sama. Dalam kasus ini, data di peroleh dari sumber terpercaya dan merupakan data yang benar dan dapat dipertanggung-jawabkan.

Teknik analisis data pada artikel ini adalah dengan menggunakan metode komparasi konstanta. Teknik analisis data dengan komparasi konstanta adalah komparasi atau perbandingan dengan menggunakan teori-teori yang sesuai kemudikan diberikan sebuah makna (Sutama, 2019). Dalam artikel ini, teori didapat dari artikel yang telah diterbitkan maupun berasal dari buku yang telah diterbitkan. Baik yang bersumber dari nasional maupun yang internasional. Proses analisis pada artikel ini adalah dengan mengumpulkan beberapa data, melakukan reduksi data, menyajikan data, dan verifikasi data serta yang terakhir adalah simpulan.

\section{HASIL DAN PEMBAHASAN}

Dalam penelitian yang telah dilakukan oleh penulis, terdapat beberapa sumber data yang relevan, berikut ini merupakan hasil yang diperoleh penulis untuk pembahasan.

1. Strategi pembelajaran hypersay dalam membantu dosen menyampaikan presentasi

$$
\text { Hypersay merupakan media }
$$
pembelajaran jarak jauh yang sangat membantu dosen untuk menyampaikan pembelajaran, akan tetapi media ini kurang familiar dikalangan dosen sehingga pemanfaatannya untuk saat ini bisa dikatakan cukup rendah. Untuk menyampaikan pembelajaran jarak jauh, media yang biasa digunakan oleh dosen yaitu seperti zoom, google meet dan google classroom. Hal ini dikarenakan media tersebut sudah sangat umum dan sering digunakan oleh dosen sehingga tidak perlu lama untuk beradaptasi menggunakan media tersebut. 


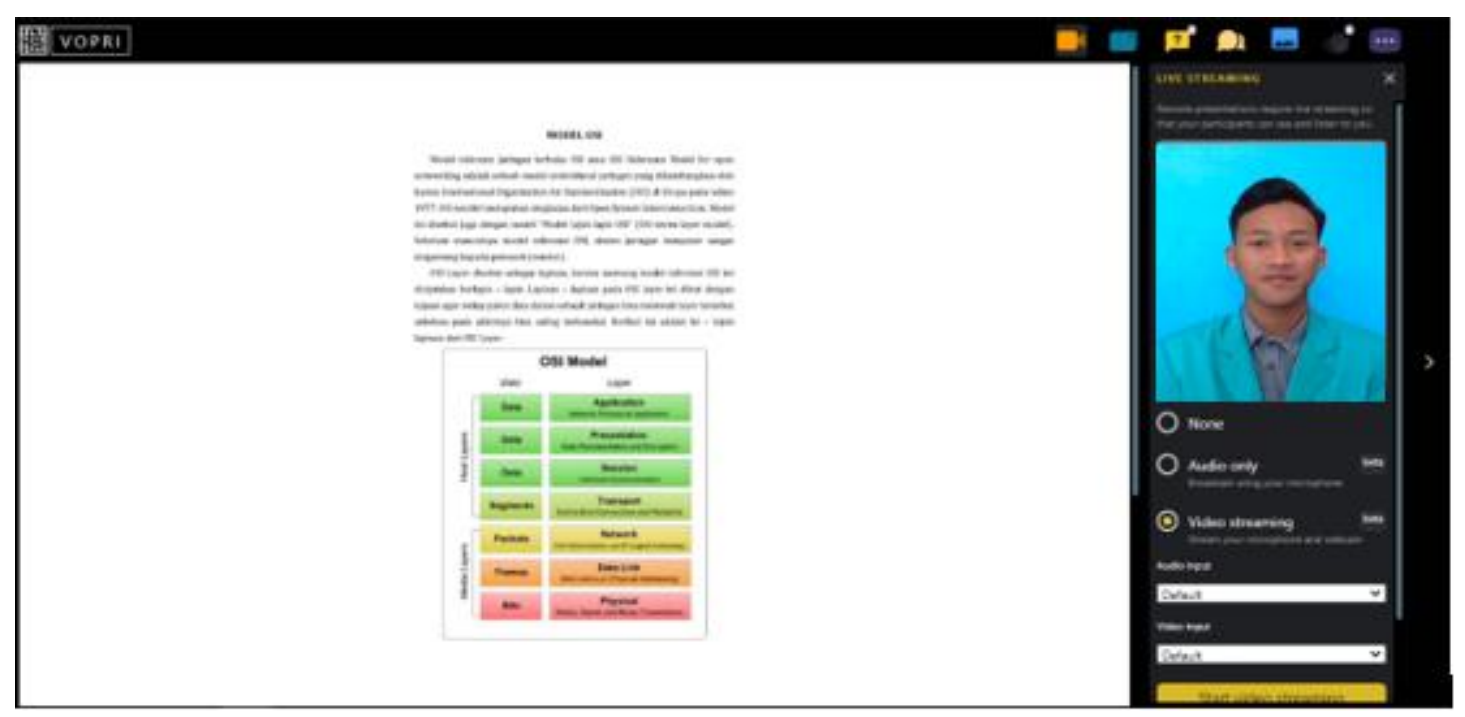

Gambar 1: Live presentasi pembelajaran

Gambar diatas merupakan sebuah contoh presentasi pembelajaran menggunakan hypersay yaitu dengan cara live presentasi, terdapat juga menu audio dan custom video streaming. Menurut (Joni Purwono, dkk, 2014) media pembelajaran memiliki peranan penting dalam menunjang kualitas proses belajar mengajar. Media juga dapat membuat pembelajaran lebih menarik dan menyenangkan. Dari pengertian di atas dapat disimpulkan bahwa media pembelajaran adalah alat bantu dalam proses belajar mengajaruntuk merangsang pikiran, perasaan, perhatian dan kemampuan atau ketrampilan pembelajar sehingga dapat mendorong terjadinya proses belajar.

Menurut Kamus Besar Bahasa Indonesia edisi kedua (1989) strategi adalah ilmu dan seni menggunakan semua sumber daya bangsa-bangsa untuk melaksanakan kebijaksanaan tertentu dalam perang dan damai. Strategi adalah serangkaian keputusan yang disusun oleh manajemen puncak dan diimplementasikan oleh seluruh jajaran suatu organisasi dalam rangka menjapai tujuan organisasi (Siagian, 2004). Strategi pembelajaran ini diperlukan agar proses belajar mengajar ditengah pandemi ini dapat berjalan secara efektif dan efisien, sehingga tujuan pembelajaran dapat tercapai secara maksimal.

Menurut Soemosasmito (dalam Trianto, 2009) sebuah pembelajaran bisa dikatakan efektif apabila telah memenuhi persyaratan utama keefektifan antara lain mengembangkan suasana belajar yang akrab dan positif, presentasi waktu belajar siswa yang tinggi dilihatkan dalam KBM. Dalam penyusunan strategi pembelajaran di tengah pandemi ini hal yang perlu diperhatikan adalah kenyamanan mahasiswa dalam melakukan pembelajaran. Oleh karena itu, dosen sebaiknya menyusun materi yang tidak terlalu memberatkan mahasiswa sehingga pembelajaran dapat berjalan secara efektif, efisien dan tujuan pembelajaran 
dapat tercapai maksimal. Media hypersay ini menjadi alternatif pembelajaran di tengah pandemi yang fitur-fiturnya mendukung dalam pembelajaran jarak jauh.

Strategi pembelajaran yang disusun penulis yang pertama yaitu dosen menyampaikan materi pembelajaran dengan cara live presentasi menggunakan media hypersay sehingga dosen tetap bisa melakukan pembelajaran dimasa pandemi ini dengan mudah. Kemudian dosen membagi mahasiswa menjadi beberapa kelompok dan diberikan materi untuk bahan diskusi melalui media hypersay. Kelompok diskusi yang sudah selesai bisa langsung mempresentasikan hasil diskusinya secara bergantian melalui live presentasi menggunakan media hypersay. Ketika kegiatan presentasi selesai dosen langsung bisa memberikan sebuah quiz yang bisa berupa materi yang berkaitan dengan pembelajaran maupun game, sehingga mahasiswa tidak merasa bosan ketika pembelajaran dilakukan secara online.

Berdasarkan uraian diatas, dapat diketahui bahwa penggunaan strategi pembelajaran menggunakan media hypersay perlu memperhatikan beberapa aspek sehingga pembelajaran yang disampaikan oleh dosen dapat diterima dengan baik oleh mahasiswa.

2. Peran hypersay dalam membantu dosen menyampaikan presentasi pembelajaran

Berdasarkan dari hasil penelitian, penggunaan media hypersay memudahkan dosen sekaligus mahasiswa untuk melakukan kegiatan pembelajaran. Media ini sangat cocok untuk digunakan dalam pembelajaran di tengah pandemi ini, sehingga kegiatan belajar mengajar tetap bisa dilakukan meskipun tidak secara tatap muka. Kelebihan media ini yaitu, pada akhir proses pembelajaran terdapat sebuah session analytics yang dapat membantu dosen dalam memberikan sebuah penilaian.

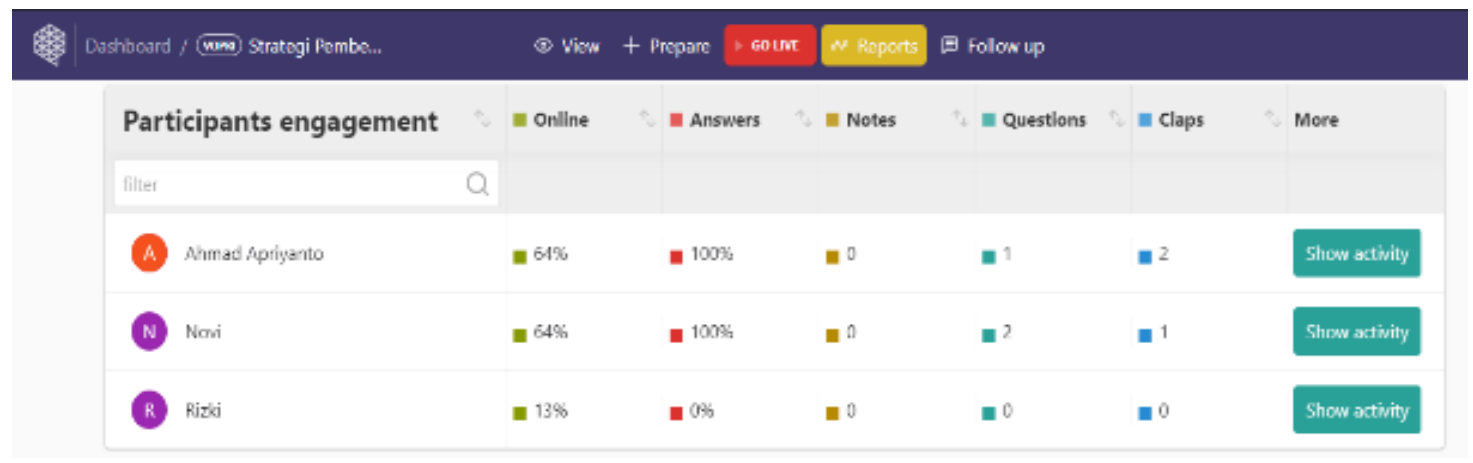

Gambar 2: Kelebihan hypersay

Media pembelajaran dapat terjadinya interaksi langsung dengan guru, memberikan kesamaan pengalaman kepada siswa tentang peristiwa-peristiwa di masyarakat, dan lingkungannya misalnya lingkungan mereka, serta memungkinkan melalui karya wisata (Azhar Arsyad, 2007). Langkah pembelajaran yang dinilai cukup 
jelas diharapkan memberikan implikasi yang baik bagi mahasiswa untuk lebih mudah menggunakan media yang disediakan dalam memahami materi yang disampaikan (Varma dan Linn, 2011). Kedudukan media tentunya sangat penting, sebab media berfungsi sebagai perantara, maka akan mampu menutupi kekurangan penyampaian pengajar dalam pembelajaran (Kwartolo, 2009).

\section{hypersay}

Live Presentation

Gambar 3: Tampilan awal media hypersay

Sumber: https://hypersay.com/

Penggunaan hypersay oleh dosen dalam pembelajaran online dapat dikatakan masih baru, karena media ini belum banyak diketahui oleh tenaga pengajar. Media yang biasa digunakan kebanyakan dosen untuk pembelajaran online tentunya adalah media yang sudah familiar seperti zoom, google meet, slido. Akan tetapi, media hypersay ini dapat dijadikan inovasi baru pembelajaran online karena fitur-fitur yang terkandung sangat mendukung dan lebih lengkap, sehingga dapat memudahkan dosen dalam melakukan pembelajaran di tengah pandemi Covid-19 ini.

Menurut pendapat (Azhar, 2011) peran media pembelajaran yaitu untuk alat bantu saat proses pembelajaran yang berada di dalam maupun di luar kelas, kemudian lebih lanjut dijelaskan bahwa media pembelajaran merupakan komponen sumber belajar yang mengandung sebuah materi yang bersifat instruksional di lingkungan siswa yang dapat merangsang siswa untuk melakukan pembelajaran. Menurut Nana sudjana manfaat media dalam proses belajar siswa adalah pengajaran akan lebih menarik perhatian siswa, bahan pengajaran lebih jelas maknanya sehingga mudah dipahami, metode pengajaran juga akan lebih bervariasi dan juga siswa lebih banyak melakukian kegiatan belajar, karena tidak semata-mata hanya mendengarkan guru, tetapi juga melakukan aktivitas lain seperti mengamati, melakukan, mendemonstrasikan dan lain-lain. 
Peran media ini dalam pembelajaran online salah satunya adalah membantu dosen untuk menyampaikan live presentasi yang berupa file powerpoint maupun pdf. Dengan adanya live presentasi ini, dosen lebih mudah menyampaikan materi pembelajaran yang sekaligus bisa dijelaskan melalui audio. Selain itu terdapat fitur pendukung yaitu seperti live quiz, live streaming, Question and Answer. Di akhir sesi pembelajaran, media ini menyediakan fitur berupa grafik penilaian tiap mahasiswa yang dilihat dari keaktifan, menjawab pertanyaan dan seluruh kegiatan selama pembelajaran berlangsung. Sehingga dosen akan lebih mudah dalam memberikan nilai secara maksimal kepada mahasiswa.

\section{Dampak penggunaan hypersay dalam} pembelajaran di tengah pandemi

Penggunaan media hypersay dalam pembelajaran ini akan menimbulkan dampak yang positif bagi proses belajar mengajar. Salah satunya adalah memudahkan dosen dalam melakukan pembelajaran. Hal ini dikarenakan pada masa pandemi ini pembelajaran tidak bisa dilakukan secara tatap muka, akan tetapi pembelajaran semaksimal mungkin harus tetap dilaksanakan secara online. Sehingga media ini dijadikan alternatif solusi untuk menyampaikan materi pembelajaran kepada mahasiswa.

$\begin{array}{rrr}\text { Pembelajaran } & \text { pada } & \text { dasarnya } \\ \text { merupakan suatu } & \text { proses interaksi }\end{array}$
komunikasi antara sumber belajar, guru, dan siswa. Interaksi komunikasi itu dilakukan baik secara langsung dalam kegiatan tatap muka maupun secara tidak langsung dengan menggunakan media, di mana sebelumnya telah menentukan model pembelajaran yang akan diterapkan tentunya (Rusman, 2012:16). Keberagaman media dalam pembelajaran ilmu sosial akan sangat membantu guru terutama dalam pemilihan jenis media yang tepat dan sesuai dengan kebutuhan pembelajaran pada berbagai konsep dan tujuan instruksional (Banks dan Cleggs, 1990:258).

Pentingnya menggunakan media pembelajaran ini didukung oleh penelitian yang dilakukan oleh (Sangsawang, 2014) yang menunjukkan bahwa penerapan media yang penampilannya menyesuaikan dengan lingkungan, kondisi peserta didik dan materi yang dibahas, juga mampu menghadirkan kehadapan peserta didik mengenai kondisi yang sebenarnya terdapat kehidupan nyata berpengaruh positif dan signifikan terhadap hasil belajar peserta didik.

Dampak penggunaan media hypersay dalam pembelajaran di tengah pandemi sangat positif. Media ini digunakan dalam menyampaikan materi pembelajaran online. Selain itu fitur-fitur yang disediakan oleh media ini sangatlah lengkap, sehingga dalam suatu pembelajaran tidak perlu membutuhkan banyak media pembelajaran untuk dikolaborasikan. Meskipun bagus, penggunaan media pembelajaran yang terlalu banyak akan mempersingkat 
penyampaian materi pembelajaran dikarenakan berpindah ke media pembelajaran akan membutuhkan waktu yang lumayan banyak.

Media hypersay di desain dengan fitur-fitur yang mencakup media kolaborasi, misalnya live presentasi dengan live quiz. Hal ini bertujuan agar mahasiswa tetap terfokus terhadap materi pembelajaran yang disampaikan. Namun, apabila penggunaan media pembelajaran lebih dari satu, maka ketika berpindah ke media yang lain pada saat pembelajaran akan memecah konsentrasi belajar mahasiswa.

\section{SIMPULAN DAN SARAN}

Berdasarkan uraian diatas, dapat diketahui bahwa dalam penyusunan strategi pembelajaran menggunakan media hypersay harus memperhatikan beberapa aspek agar mahasiswa dapat mengikuti pembelajaran secara nyaman dan maksimal, sehingga tujuan pembelajaran akan tercapai dengan baik.

Di tengah pandemi ini, media hypersay berperan dalam membantu proses pembelajaran secara online. Salah satunya adalah membantu dosen untuk menyampaikan live presentasi yang berupa file powerpoint maupun pdf. Dengan adanya live presentasi ini, dosen lebih mudah menyampaikan materi pembelajaran yang sekaligus bisa dijelaskan melalui audio. Selain itu terdapat fitur pendukung yaitu seperti live quiz, live streaming, Question and Answer. Di akhir sesi pembelajaran, media ini menyediakan fitur berupa grafik penilaian tiap mahasiswa yang dilihat dari keaktifan, menjawab pertanyaan dan seluruh kegiatan selama pembelajaran berlangsung. Sehingga dosen akan lebih mudah dalam memberikan nilai secara maksimal kepada mahasiswa.

Penggunaan media hypersay dalam pembelajaran di tengah pandemi berdampak yang baik bagi dosen dan mahasiswa. Hal ini dikarenakan fitur yang terdapat dalam media ini mendukung proses pembelajaran secara online. Sehingga pembelajaran yang disampaikan oleh dosen dapat berjalan secara efektif dan efisien.

Pada kesempatan ini ada beberapa ucapan terimakasih yang perlu penulis sampaikan. Ucapan terimakasih penulis sampaikan kepada Dekan Fakultas Keguruan dan Ilmu Pendidikan Universitas Muhammadiyah Surakarta beserta jajarannya. Terimakasih sekali atas izin perkuliahan ini sehingga bisa berjalan sesuai yang penulis harapkan. Ucapan terimakasih juga disampaikan kepada yang terhormat Pimpinan Program Studi Pendidikan Teknik Informatika Fakultas Keguruan dan Ilmu Pendidikan Universitas Muhammadiyah Surakarta yang telah membimbing penulis sehingga dapat belajar sesuai yang penulis harapkan. 


\section{DAFTAR REFERENSI}

Darmalaksana, W., Hambali, R. Y. A., Masrur, A., \& Muhlas. (2020). Analisis Pembelajaran Online Masa WFH Pandemic Covid-19 sebagai Tantangan Pemimpin Digital Abad 21. UIN Sunan Gunung Djati Bandung, 1(1), 1-12.

Taufik; Ayuningtyas. (2020). The Impact of Covid-19 Pandemic on Business and Online Platform Existance. Jurnal Pengembangan Wiraswasta, 22(1), 2132.

Hertiavi, M. A. (2020). Penerapan E-Learning dengan Platform Edmodo untuk Meningkatkan Hasil Belajar Mahasiswa. Jurnal Komunikasi Pendidikan, 4(1), 1-8.

Mansur, H. (2020). Pengembangan Media Pembelajaran Infografis untuk Meningkatkan Minat Belajar Mahasiswa Developing Infographical Media i n Learning To Increase The Students ' Interest. 4(1), 37-48.

Sutama. (2019). Metode Penelitian Pendidikan Kuantitatif, Kualitatif, PTK, Mix Method, R\&D. Sukoharjo, Indonesia: Jasmine.

Nurwidayanti, D., \& Mukminan, M. (2018). Pengaruh media pembelajaran terhadap hasil belajar ekonomi ditinjau dari gaya belajar siswa SMA Negeri. Harmoni Sosial: Jurnal Pendidikan IPS, 5(2), 105114.

https://doi.org/10.21831/hsjpi.v5i2.17743

Tafonao, T. (2018). Peranan Media Pembelajaran Dalam Meningkatkan Minat Belajar Mahasiswa. Jurnal Komunikasi Pendidikan, 2(2), 103. https://doi.org/10.32585/jkp.v2i2.113

Madrasah Aliah Negeri Se-Jakarta Selatan. Edusains, 6(1), 67-72. https://doi.org/10.15408/es.v6i1.1101

Ahmad Johari Sihes. (2015). Konsep Pembelajaran. E-Prints UTM, 8. http://repository.usu.ac.id/bitstream/12345 6789/23790/4/Chapter I.pdf

Hanum, N. S. (2013). Keefetifan e-learning sebagai media pembelajaran (studi evaluasi model pembelajaran e-learning SMK Telkom Sandhy Putra Purwokerto). Jurnal Pendidikan Vokasi, 3(1), 90-102. https://doi.org/10.21831/jpv.v3i1.1584

. M. (2012). Strategi Pembelajaran (Pengantar Kajian Pembelajaran Efektif). In Jurnal Visi Ilmu Pendidikan (Vol. 4, Issue 1). https://doi.org/10.26418/jvip.v4i1.341
Fatimah, F., \& Kartikasari, R. D. (2018). Strategi Belajar Dan Pembelajaran Dalam Meningkatkan Keterampilan Bahasa. Pena Literasi, 1(2), 108. https://doi.org/10.24853/pl.1.2.108-113

Kuswanto, J., \& Radiansah, F. (2018). Media Pembelajaran Berbasis Android Pada Mata Pelajaran Sistem Operasi Jaringan Kelas XI. An Nabighoh Jurnal Pendidikan Dan Pembelajaran Bahasa Arab, 14(01), 129. https://doi.org/10.32332/annabighoh.v20i01.1131

Srimaya, S. (2017). Efektivitas Media Pembelajaran Power Point Untuk Meningkatkan Motivasi Dan Hasil Belajar Biologi Siswa. Jurnal Biotek, 5(1), 53-68. https://doi.org/10.24252/JB.V5I1.3446

Putri, W. N. (2017). Pengaruh Media Pembelajaran Terhadap Motivasi Belajar Bahasa Arab Siswa Madrasah Tsanawiyah. LISANIA: Journal of Arabic Education and Literature, 1(1), 1. https://doi.org/10.18326/lisania.v1i1.1160

Hayes, C., Hardian, H., \& Sumekar, T. (2017). Pengaruh Brain Training Terhadap Tingkat Inteligensia Pada Kelompok Usia Dewasa Muda. Jurnal Kedokteran Diponegoro, 6(2), 402-416.

Ismawati, L. (2017). Pengaruh Media Pembelajaran dan Motivasi Berprestasi Terhadap Hasil Belajar Peserta Didik MAN Di Kabupaten Gresik. JPEKA: Jurnal Pendidikan Ekonomi, Manajemen Dan Keuangan, 1(2), 091-104. https://doi.org/10.26740/jpeka.v1n2.p091$\underline{104}$

Primasari, R., \& Herlanti, Y. (2015). Penggunaan Media Pembelajaran Di Universitas, F., Yogyakarta, N., Penelitian, A., \& Kimia, J. P. (2012). Pengaruh Media Pembelajaran Interaktif Berbasis Web Terhadap Motivasi Belajar Mahasiswa. Pengaruh Media Pembelajaran Interaktif Berbasis Web Terhadap Motivasi Belajar Mahasiswa, 42(2), 99-109.

https://doi.org/10.21831/jk.v42i2.2236

Muhammad, R. (2011). Pengaruh Pemanfaatan Media Pembelajaran Film Animasi Terhadap Hasil Belajar. Jurnal Penelitian Pendidikan, Edisi Khus(1), 154-163.

Susilana, R \& Riyana, C. (2009). MEDIA PEMBELAJARAN:

Hakikat,Pengembangan,Pemanfaatan, dan Penilaian. 